\title{
Industrialization of housing construction as a tool for sustainable settlement and rural areas development
}

\author{
Olga Popova $^{1, *}$, Polina Antufieva ${ }^{1}$, Vladimir Grebenshchikov $^{2}$ and Mariya Balmashnova ${ }^{2}$ \\ ${ }^{1}$ Northern (Arctic) Federal University named after M.V. Lomonosov, 163002, Severnaya Dvina \\ Emb., 17, Arkhangelsk, Russia \\ ${ }^{2}$ Moscow State University of Civil Engineering, 26, Yaroslavskoeshosse, 129337, Moscow, Russia
}

\begin{abstract}
The development of the construction industry, conducting construction in accordance with standard projects, and transforming the construction materials industry in hard-to-reach and sparsely populated areas will make significant progress in solving the housing problem. Industrialization of housing construction is a catalyst for strong growth of the region's economy and the quality of life of citizens. The purpose of this study is to develop a methodology for assessing the level of industrialization of the territory's construction complex and its development potential for increasing the volume of low-rise housing stock. Research tasks: 1) assessment of the need to develop housing construction, including low-rise housing, on a particular territory; 2) development of a methodology for calculating the level of industrialization of construction in the area under consideration to determine the possibility of developing low-rise housing construction in this area in the proposed way; 3 ) approbation of the method using the example of rural areas of the Arkhangelsk region. It was revealed that the districts of the Arkhangelsk region have medium and low levels of industrialization. The districts that are most in need of an increase in the rate of housing construction have been identified. Recommendations for the development of the construction industry in certain areas have been developed.
\end{abstract}

\section{Introduction}

The goal of the social policy of the Russian Federation is to improve the quality of life of the population. One of the main tools to increase it is to improve housing conditions.

Russia lags significantly behind European countries and the United States in terms of housing provision (figure 1).

\footnotetext{
*Corresponding author: oly-popova@yandex.ru
} 


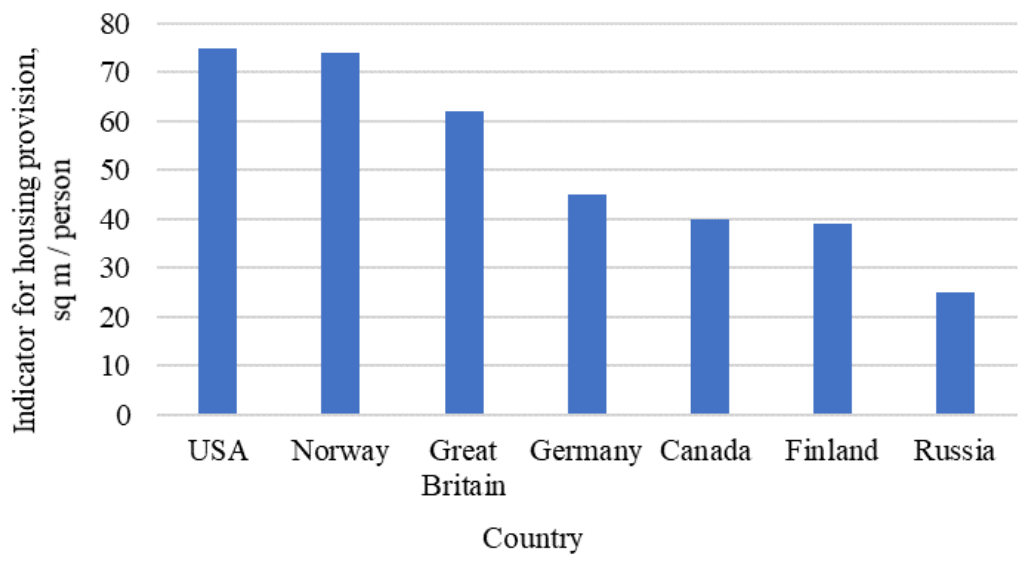

Fig. 1. Provision of housing for the population.

Analysis of the housing stock of the Russian Federation showed that most of the Russian population lives in apartment buildings of medium and high floors. The total area of apartments as of 2017 was 78.6 million square meters, and private houses-32.7 million square meters, which is about $30 \%$ of the total housing stock. At the same time, this figure in the US is $83 \%$.

At the same time, the level of urbanization in Russia is $74.3 \%$ with an urban area of 8.38 million hectares, which is $0.5 \%$ of the total area of the country (figure 2). For comparison, in a much smaller area of France, urban land accounts for $16 \%$.

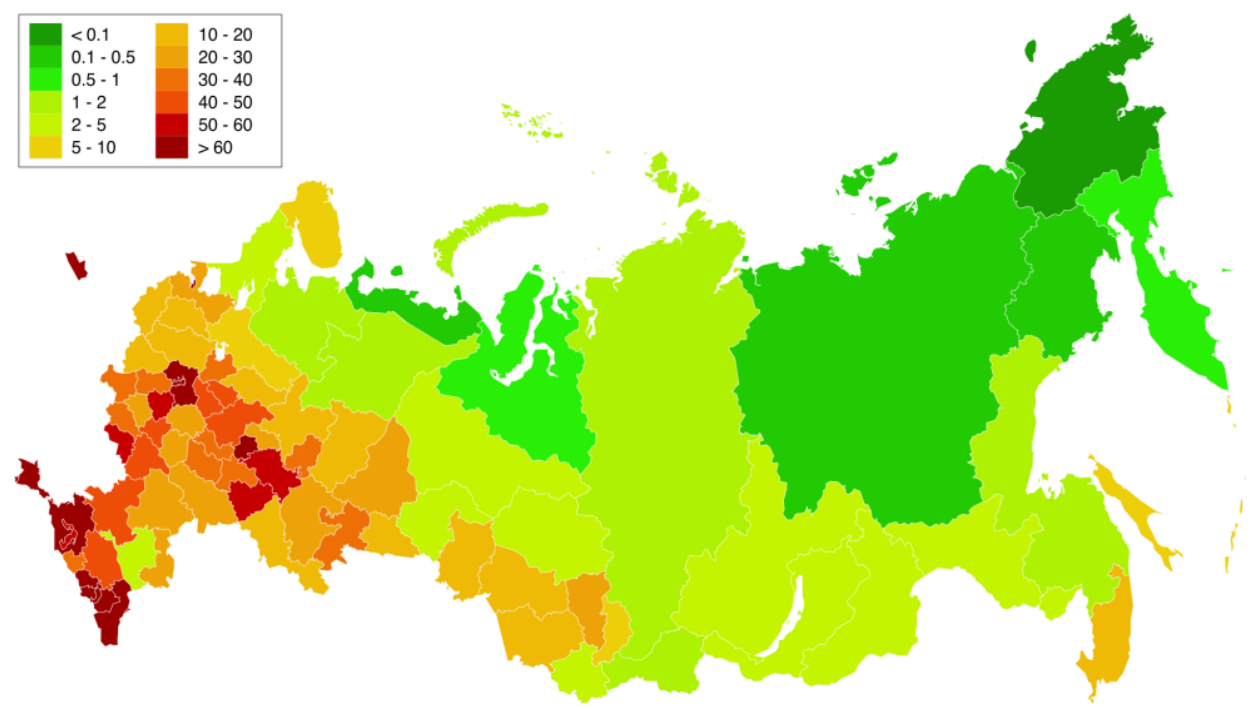

Fig. 2. Population density of Russian regions as of 01.01.2019.

According to the data provided in the spatial development Strategy of the Russian Federation for the period up to 2025 (hereinafter-the strategy), over the past 10 years, there has been a gradual reduction in migration outflow from Eastern Siberia and the Northern regions of the European part of the Russian Federation, from the Far East. There is a steady decline in the population of cities with a population of less than 100 thousand, also of rural areas, with the exception of most of the southern regions of the European part of the 
Russian Federation and the territories of localities that are part of major urban agglomerations and major urban agglomerations.

In such circumstances, it is particularly important to address the objectives of the strategy, which include reducing the level of interregional differentiation in the social and economic development of subjects of of the Russian Federation, as well as reducing intraregional social and economic differences by increasing the stability of the settlement system through the social and economic development of cities and rural areas and ensuring a steady increase in the number of permanent population in these territories.

The analysis indicates the following problems:

- high demand of the population for housing;

- the presence of undeveloped or small-developed territories.

Given the low population density and inaccessibility of developing areas, the solution to the problem of providing quality and comfortable housing can be a low-rise housing construction by industrialization, the increase of which at the moment is at a low level.

Research in the field of construction industrialization is mainly aimed at studying the use of information technologies as a decision-making tool at a particular stage of the object creation cycle in an industrial way [1-7]. Some research papers are devoted to the use of prefabricated structures manufactured in the factory, the use of which helps to reduce the time of installation of the building and improve the quality of construction products [8-15]. There are also scientific studies related to assessing the magnitude of the reduction in the cost of housing in the industrial construction of residential buildings [16], analyzing the advantages and disadvantages of residential premises in modular homes in the opinion of their residents and determining ways to eliminate the identified problems [17], studying the barriers to the development of industrial construction and ways to overcome them [18].

Industrialization in construction is the process of developing and improving the use of large-scale elements of buildings of high factory readiness, using the means of mechanization and automation of construction processes.

Industrialization in construction allows getting the following effects:

- accelerate the pace of construction;

- reducing its cost price;

- improving the quality of construction;

- increase productivity;

- increasing the degree of factory readiness of building structures and parts;

- expansion of full-scale construction;

- ensuring mass application of new efficient materials and lightweight structures in the wide use of local building materials.

Thus, the industrialization of housing construction creates conditions for increasing the level of housing affordability for the population.

The purpose of this study is to develop a methodology for assessing the level of industrialization of the territory's construction complex and its development potential for increasing the volume of low-rise housing stock.

Research tasks are the following:

1) assessment of the need to develop housing construction, including low-rise housing, on a particular territory;

2) development of a methodology for calculating the level of industrialization of construction in the area under consideration to determine the possibility of developing lowrise housing construction in this area in the proposed way;

3) approbation of the method using the example of rural areas of the Arkhangelsk region. 


\section{Method}

\subsection{Assessment of the level of housing provision for the population of territories}

Individual territories differ in the level of housing provision. The implementation of various programs to improve housing affordability should primarily target areas with a low level of this indicator. At the moment, the standard of housing security set by the UN is 30 sq. m. / person.

We assess the level of housing security using the following parameters of the territory:

- the general level of housing provision for the population;

- the level of provision of the population with housing suitable for living;

- rate of change in total housing;

- the rate of change in the volume of housing suitable for living;

- the rate of population change.

To take into account the dynamics of changes in these indicators, the average values for a certain time period are taken into account.

The indicator of the population's availability of living space $O$, sq. m/person, is calculated using the formula:

$$
O=S / N
$$

where $S$ - is the total area of residential premises suitable for living, located on a particular territory, sq. m;

$N$ - the number of people living in this territory, people.

The rate of change in the volume of housing is defined as the ratio of the value of the volume of housing for the current period to the previous one. The average value is calculated using the formula:

$$
t^{\prime}=\left(t_{1} \cdot t_{2} \cdot \ldots \cdot t_{\mathrm{a}}\right)^{\wedge}(1 / a)
$$

where $t_{1 \ldots a}$ - is the rate of change in the volume of housing for a particular period (year),

$a-$ the number of periods.

Increasing the rate of housing construction to improve the quality of life of the population is required in districts:

- where the indicator of housing provision is less than the standard value set by the UN in the amount of 30 sq. m. / person.,

- subject to negative rates of change in the volume of housing stock suitable for living,

- if the rate of housing reproduction is less than or equal to the rate of retirement of the housing stock.

\subsection{Assessment of the level of industrialization of low-rise construction of the territory}

To assess the level of industrialization, it is necessary to define a list of its features and their quantitative description.

The study considered the following elements of industrialization of construction production: 
- availability of standard construction projects in the territory / register of project documentation for reuse;

- industrial production of materials and structures for housing construction;

- industrial construction of residential buildings - construction is carried out in a contract way by specialized construction and installation organizations registered in the territory.

\subsubsection{Assessment of the level of industrialization based on the criteria for the availability of standard construction projects}

The Ministry of construction of the Russian Federation has been creating a register of standard project documentation since 2011 (hereinafter-the register), which includes projects for various purposes, including low-rise residential buildings. According to the guidelines for the use of standard project documentation, the cost of acquiring the right to use it is up to $10 \%$ of the cost of developing project documentation. The use of reuse projects can significantly reduce the time and cost of developing project documentation, which is typical for industrial housing construction.

According to the Rules for creating and maintaining a register of standard project documentation, the project is subject to inclusion in the register of project documentation for reuse if it meets the following criteria:

1) the presence of a positive conclusion of the State Experise of project documentation;

2 ) indicators of the cost of project documentation should not exceed the indicators of the construction price standards for similar objects;

3 ) the ratio of useful area to total area of object of capital construction should not be lower than the target set by the Ministry of construction and housing and communal services;

4) the presence of an energy passport or calculations in the project, confirming the energy efficiency of the building at a level not lower than class "C";

5) the project documentation must comply with the current requirements established for architectural and planning, technological and organizational solutions (SanPiN, SP, GOST, etc.);

6) the use of advanced architectural and planning, design and engineering solutions, energy-efficient technologies, environmental and innovative building materials and products in the design.

Currently, the register is being gradually updated with new projects of capital construction projects.

At the moment, the register includes the following number of typical projects of lowrise residential buildings (Table 1).

Table 1. Number of typical projects of low-rise residential buildings in the register.

\begin{tabular}{|c|c|c|c|c|}
\hline $\begin{array}{c}\text { Subject of the } \\
\text { Russian } \\
\text { Federation }\end{array}$ & Human settlement & $\begin{array}{c}\text { Number of } \\
\text { standard projects } \\
\text { of low-rise } \\
\text { apartment } \\
\text { buildings in the } \\
\text { register }\end{array}$ & $\begin{array}{c}\text { Number of } \\
\text { standard projects } \\
\text { of individual } \\
\text { residential } \\
\text { buildings in the } \\
\text { register }\end{array}$ & $\begin{array}{c}\text { Total } \\
\text { number of } \\
\text { standard } \\
\text { projects of } \\
\text { low-rise } \\
\text { residential } \\
\text { buildings }\end{array}$ \\
\hline Primorsky Krai & Vladivostok & 5 & 3 & 8 \\
\hline Moscow Oblast & Istra & 4 & - & 4 \\
\hline $\begin{array}{c}\text { Volgograd } \\
\text { Oblast }\end{array}$ & Nikolaevsk & 1 & - & 1 \\
\hline Bashkortostan & Iglino & 1 & - & 1 \\
\hline
\end{tabular}




\begin{tabular}{|c|c|c|c|c|}
\hline $\begin{array}{c}\text { Subject of the } \\
\text { Russian } \\
\text { Federation }\end{array}$ & Human settlement & $\begin{array}{c}\text { Number of } \\
\text { standard projects } \\
\text { of low-rise } \\
\text { apartment } \\
\text { buildings in the } \\
\text { register }\end{array}$ & $\begin{array}{c}\text { Number of } \\
\text { standard projects } \\
\text { of individual } \\
\text { residential } \\
\text { buildings in the } \\
\text { register }\end{array}$ & $\begin{array}{c}\text { Total } \\
\text { number of } \\
\text { standard } \\
\text { projects of } \\
\text { low-rise } \\
\text { residential } \\
\text { buildings }\end{array}$ \\
\hline Republic & Saratov & 2 & 1 & 3 \\
\hline Saratov Oblast & Gribanovsky & 2 & - & 2 \\
\hline Voronezh Oblast & Novosibirsk & 4 & 2 & 13 \\
\hline Krasnodar Krai & Ekaterinburg & 1 & 1 & 2 \\
\hline $\begin{array}{c}\text { Novosibirsk } \\
\text { Oblast }\end{array}$ & 27 & 13 & 40 \\
\hline $\begin{array}{c}\text { Sverdlovsk } \\
\text { Oblast }\end{array}$ & 3 & 2 & 5 \\
\hline \multicolumn{2}{|c|}{ Total } & 7 & 6 & 6 \\
\hline $\begin{array}{c}\text { The average number of standard projects } \\
\text { in the region }\end{array}$ &
\end{tabular}

Based on the analysis of the register of standard project documentation for low-rise housing construction, we can conclude that for most of the subjects of the Russian Federation, this criterion is absent.

As an estimated parameter $K_{1}$ we take the following calculation formula:

$$
K_{1}=P_{1} / P
$$

where $P_{1}$ is the number of standard projects in the register for the territory under consideration;

$P$ - the average national indicator of the presence of standard projects of low-rise residential buildings in the register of standard project documentation.

If the number of standard projects of low-rise residential buildings in the register of standard project documentation for the region in question is higher than the average national $P_{\mathrm{r}}$ indicator, then the estimated parameter $K_{1}$ is assumed to be 1 .

\subsubsection{Industrial production of materials and structures for low-rise housing construction}

To assess the level of industrialization based on the presence of the criterion "industrial production of building materials and structures" in the districts, it is proposed to analyze the relevant enterprises in the region and assess their distance from municipal districts.

In this case, for all construction industries located in a particular area, a matrix is compiled in which points are put down for each of the districts of the region, depending on their distance from the territory where construction materials and structures are manufactured. The distance rating is from 0 to 5 points $\left(k_{\mathrm{n}}\right)$. The district where there is a production of a particular building material is assigned the highest score, the most remotethe lowest score. With limited transport accessibility the score, a measure of the remoteness of the district from production of building materials and structures located outside the area under consideration, multiplied by a factor that takes into account the period of delivery.

After setting points, the sum of the maximum points for a particular type of building material for each district is calculated:

$$
P_{2}=\Sigma(\mathrm{i}=1 ; n) k_{\mathrm{i} \max } \cdot n,
$$

where $k_{\mathrm{imax}}$ - is the maximum value of availability of building materials and structures, 
$t_{\mathrm{i}}$-coefficient of transport accessibility of the territory for delivery of the i-th type of construction material,

$n$ - the number of types of building materials or structures available in the region.

Then the obtained value is compared with the maximum possible value. The maximum value is taken based on the condition that the main types of building materials used in lowrise housing construction are available in the territory under consideration, and is determined by the formula:

$$
K_{2}=P_{2} / P_{2 \max }=P_{2} /(5 \cdot n)
$$

where 5 is the maximum value of $k_{\mathrm{i}}$,

$n$ - the number of types of building materials or structures available in the region.

\subsubsection{Industrial construction of low-rise residential buildings}

For the realization of building production requires a given territory, building organizations, implementing the basic stages of construction undertaken in accordance with the enlarged types of work: installation of foundations, construction of building frame, roofing, finishing works and construction of floors, installation of internal sanitary-engineering and electrotechnical devices - 5 types of work. Market analysis has shown that services for these types of work are offered by both specialized firms and individuals. Depending on this, districts are assigned the following points: if there are specialized organizations that carry out construction and installation work on the territory - 2 points, if these services are offered exclusively by individuals - 1 point, if there is no market for construction services0 points, after which all points are summed up. Then the ratio of the received amount of points with the maximum possible value is made, which is determined if services for all types of work are offered by specialized firms in the territory under consideration.

The $K_{3}$ criterion is calculated using the formula:

$$
K_{3}=P_{3} / P_{3 \max }
$$

where $P_{3}$ - is the score that characterizes the provision of services for the production of construction and installation works;

$P_{3 \max }-$ the maximum value assumed to be $5 \cdot 2=10$.

\subsubsection{Determining the level of industrialization of the territory}

The level of industrialization is determined by the sum of the calculated criteria, the maximum value of which is 3 . Depending on which range the total value falls within, the level of industrialization is determined: from 0 to 1 - low level; from 1 to 2 - medium level; from 2 to 3 - high level. 


\section{Results and discussions}

\subsection{Identification of territories where the population needs to develop housing construction}

The calculation of indicators from item 1 of the methodology is presented in table 2 .

Table 2. Calculation of indicators.

\begin{tabular}{|c|c|c|c|c|c|c|c|}
\hline No & 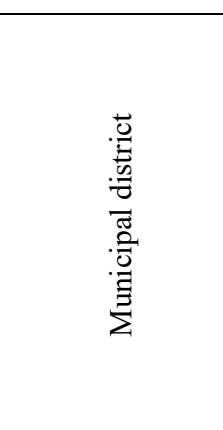 & 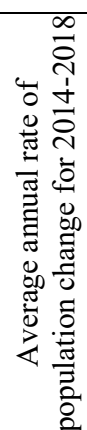 & 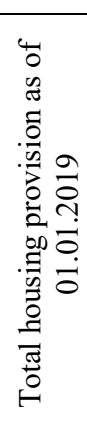 & 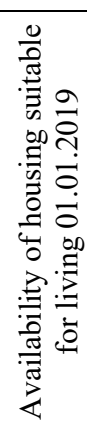 & 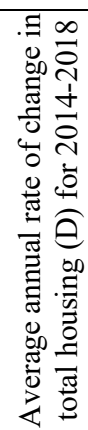 & 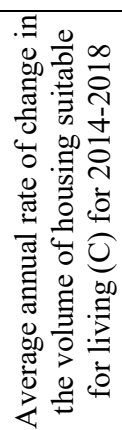 & 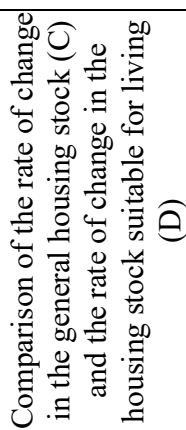 \\
\hline 1 & Leshukonsky & 0.95 & 40.7 & 39.5 & 1.01 & 1.02 & $\mathrm{D}<\mathrm{C}$ \\
\hline 2 & Kholmogorsky & 0.96 & 38.9 & 35.3 & 1.01 & 1 & $\mathrm{D}>\mathrm{C}$ \\
\hline 3 & Shenkursky & 0.96 & 35.2 & 34.6 & 1.01 & 1.01 & $\mathrm{D}=\mathrm{C}$ \\
\hline 4 & Mezensky & 0.95 & 35.9 & 32.5 & 1.01 & 1.01 & $\mathrm{D}=\mathrm{C}$ \\
\hline 5 & Pinezhsky & 0.95 & 34.8 & 31.8 & 1.01 & 1.02 & $\mathrm{D}<\mathrm{C}$ \\
\hline 6 & Primorsky & 0.99 & 33.8 & 31 & 1.01 & 1.01 & $\mathrm{D}=\mathrm{C}$ \\
\hline 7 & Krasnoborsky & 0.96 & 30.9 & 28.6 & 1.08 & 1.09 & $\mathrm{D}<\mathrm{C}$ \\
\hline 8 & Vilegodsky & 0.98 & 34.7 & 28.1 & 1.04 & 1.03 & $\mathrm{D}>\mathrm{C}$ \\
\hline 9 & Vinogradovsky & 0.97 & 30 & 27.9 & 1.05 & 1.06 & $\mathrm{D}<\mathrm{C}$ \\
\hline 10 & Kargopolsky & 0.98 & 30.4 & 25.4 & 1.02 & 1.01 & $\mathrm{D}>\mathrm{C}$ \\
\hline 11 & Verkhnetoemsky & 0.95 & 31.3 & 25.3 & 1.05 & 1.06 & $\mathrm{D}<\mathrm{C}$ \\
\hline 12 & Lensky & 0.97 & 27 & 24.5 & 1.05 & 1.09 & $\mathrm{D}<\mathrm{C}$ \\
\hline 13 & Kotlassky & 0.98 & 26.9 & 24.2 & 0.98 & 0.98 & $\mathrm{D}=\mathrm{C}$ \\
\hline 14 & Velsky & 0.98 & 24.6 & 23.1 & 0.99 & 0.99 & $\mathrm{D}=\mathrm{C}$ \\
\hline 15 & Ustyansky & 0.97 & 29.2 & 20.9 & 1.03 & 1.05 & $\mathrm{D}<\mathrm{C}$ \\
\hline 16 & Nyandomsky & 0.98 & 24 & 20.8 & 1.1 & 1.11 & $\mathrm{D}<\mathrm{C}$ \\
\hline 17 & Konoshsky & 0.97 & 24.6 & 19.4 & 1.12 & 1.11 & $\mathrm{D}>\mathrm{C}$ \\
\hline 18 & Onezhsky & 0.98 & 23 & 19.3 & 1.05 & 1.06 & $\mathrm{D}<\mathrm{C}$ \\
\hline 19 & Plesetskiy & 0.97 & 21.2 & 14.9 & 1.02 & 1 & $\mathrm{D}>\mathrm{C}$ \\
\hline
\end{tabular}

The territories most in need of increasing the rate of housing construction are: Vilegodsky, Kargopolsky, Kotlassky, Velsky, Konoshsky and Plesetsky municipal districts.

\subsection{Assessment of the level of industrialization of low-rise housing construction}

\subsubsection{Development of standard projects}

The analysis of typical projects of low-rise residential buildings contained in the register of standard project documentation showed that there is no criterion for the availability of standard projects in the Arkhangelsk region. Based on this, each district is assigned 0 points for this criterion. 


\subsubsection{Industrial production of materials and structures for low-rise housing construction}

The following construction materials production facilities are operating on the territory of the Arkhangelsk region (table 3).

Table 3. Production of construction materials on the territory of the Arkhangelsk region.

\begin{tabular}{|c|c|c|c|c|c|c|}
\hline No & 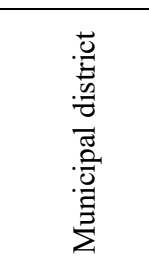 & 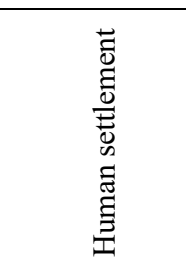 & 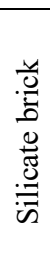 & 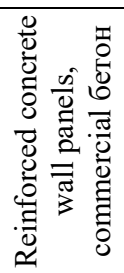 & 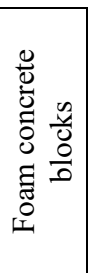 & 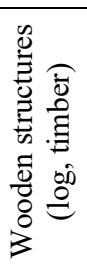 \\
\hline 1 & Velsky & Velsk & & & & + \\
\hline \multirow{2}{*}{2} & \multirow{2}{*}{ Kotlassky } & Kotlas & + & & & \\
\hline & & Koryazhma & & + & & + \\
\hline \multirow{2}{*}{3} & \multirow{2}{*}{ Primorsky } & Arkhangelsk & & + & & + \\
\hline & & Severodvinsk & & & + & \\
\hline
\end{tabular}

Analysis of the material and raw material base of the districts of the Arkhangelsk region showed that in addition to the above-mentioned building materials, it is possible to organize production of ceramic bricks and wooden wall panels on their territory.

Calculation of matrices for determining the distance of districts from the territories of production of construction materials, taking into account the above features, is presented in table 4 . When setting points, we take into account that the delivery of goods to most of the localities of Leshukonskiy and Mezenskiy districts is possible only on winter roads that operate for six months, in this connection, we apply a transport accessibility coefficient equal to 0.5 to the assessment of the remoteness of these territories.

Table 4. Calculation of the matrix of paired comparisons for the territory of existing and possible production of construction materials.

\begin{tabular}{|c|c|c|c|c|c|c|c|c|c|c|c|}
\hline \multirow[b]{2}{*}{$\mathrm{No}$} & \multirow[b]{2}{*}{$\begin{array}{c}\text { Municipal } \\
\text { district }\end{array}$} & \multirow{2}{*}{$\begin{array}{c}\text { Silicate brick } \\
\\
\\
\frac{\vec{v}}{0} \\
\frac{0}{0} \\
\frac{0}{0}\end{array}$} & \multicolumn{2}{|c|}{$\begin{array}{c}\text { Reinforced } \\
\text { concrete } \\
\text { wall } \\
\text { panels, }\end{array}$} & \multirow{2}{*}{ 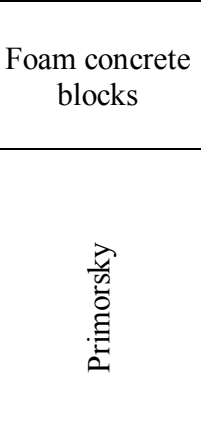 } & \multicolumn{3}{|c|}{$\begin{array}{l}\text { Wooden } \\
\text { structures }\end{array}$} & \multirow{2}{*}{ 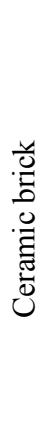 } & \multirow{2}{*}{ 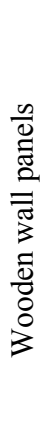 } & \multirow{2}{*}{ 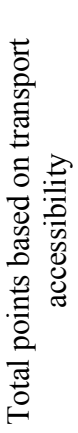 } \\
\hline & & & 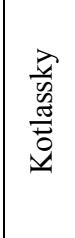 & 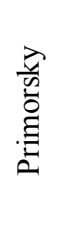 & & $\frac{\vec{v}}{\frac{v}{2}}$ & 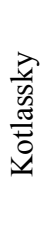 & 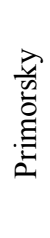 & & & \\
\hline 1 & Velsky & 3 & 3 & 1 & 1 & 5 & 3 & 1 & 0 & 0 & 12 \\
\hline 2 & Verkhnetoemsky & 3 & 3 & 2 & 2 & 3 & 3 & 2 & 0 & 0 & 11 \\
\hline 3 & Vilegodsky & 4 & 4 & 0 & 0 & 2 & 4 & 0 & 0 & 0 & 12 \\
\hline 4 & Vinogradovsky & 2 & 2 & 3 & 3 & 3 & 2 & 3 & 0 & 0 & 11 \\
\hline 5 & Kargopolsky & 1 & 1 & 2 & 2 & 3 & 1 & 2 & 0 & 0 & 8 \\
\hline 6 & Konoshsky & 2 & 2 & 1 & 1 & 4 & 2 & 1 & 0 & 0 & 9 \\
\hline 7 & Kotlassky & 5 & 5 & 0 & 0 & 3 & 5 & 0 & 0 & 0 & 15 \\
\hline 8 & Krasnoborsky & 4 & 4 & 1 & 1 & 3 & 4 & 1 & 0 & 0 & 13 \\
\hline 9 & Lensky & 4 & 4 & 0 & 0 & 2 & 4 & 0 & 0 & 0 & 12 \\
\hline
\end{tabular}




\begin{tabular}{|c|c|c|c|c|c|c|c|c|c|c|c|}
\hline \multirow[b]{2}{*}{$\mathrm{No}$} & \multirow[b]{2}{*}{$\begin{array}{c}\text { Municipal } \\
\text { district }\end{array}$} & \multirow{2}{*}{$\begin{array}{c}\text { Silicate brick } \\
\\
\frac{\vec{v}}{0} \\
\frac{0}{0} \\
\frac{0}{0} \\
v\end{array}$} & \multicolumn{2}{|c|}{$\begin{array}{l}\text { Reinforced } \\
\text { concrete } \\
\text { wall } \\
\text { panels, }\end{array}$} & \multirow{2}{*}{$\begin{array}{c}\begin{array}{c}\text { Foam concrete } \\
\text { blocks }\end{array} \\
\\
\end{array}$} & \multicolumn{3}{|c|}{$\begin{array}{l}\text { Wooden } \\
\text { structures }\end{array}$} & \multirow{2}{*}{ 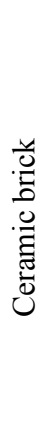 } & \multirow{2}{*}{ 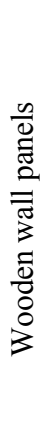 } & \multirow{2}{*}{ 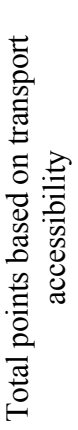 } \\
\hline & & & 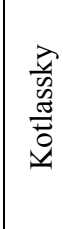 & 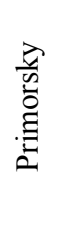 & & $\frac{\vec{a}}{\frac{a}{0}}$ & 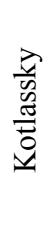 & 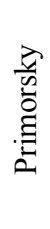 & & & \\
\hline 10 & Leshukonsky & 0 & 0 & 3 & 3 & 0 & 0 & 3 & 0 & 0 & 4,5 \\
\hline 11 & Mezensky & 0 & 0 & 4 & 4 & 0 & 0 & 4 & 0 & 0 & 6 \\
\hline 12 & Nyandomsky & 2 & 2 & 2 & 2 & 4 & 2 & 2 & 0 & 0 & 10 \\
\hline 13 & Onezhsky & 0 & 0 & 4 & 4 & 2 & 0 & 4 & 0 & 0 & 12 \\
\hline 14 & Pinezhsky & 1 & 1 & 4 & 4 & 2 & 1 & 4 & 0 & 0 & 13 \\
\hline 15 & Plesetskiy & 1 & 1 & 3 & 3 & 3 & 1 & 3 & 0 & 0 & 10 \\
\hline 16 & Primorsky & 0 & 0 & 5 & 5 & 0 & 0 & 5 & 0 & 0 & 15 \\
\hline 17 & Ustyansky & 4 & 4 & 1 & 1 & 4 & 4 & 1 & 0 & 0 & 13 \\
\hline 18 & Kholmogorsky & 1 & 1 & 4 & 4 & 2 & 1 & 4 & 0 & 0 & 13 \\
\hline 19 & Shenkursky & 3 & 3 & 2 & 2 & 4 & 3 & 2 & 0 & 0 & 12 \\
\hline
\end{tabular}

The optimal value is calculated based on the above data. The calculation of the $K_{2}$ criterion is presented in table 5 .

Table 5. $K_{2}$ criterion calculation.

\begin{tabular}{|c|c|c|c|c|}
\hline No & Municipal District & Sum of points & Maximum value & Criterion $K_{2}$ \\
\hline 1 & Velsky & 12 & 30 & 0.40 \\
\hline 2 & Verkhnetoemsky & 11 & 30 & 0.37 \\
\hline 3 & Vilegodsky & 12 & 30 & 0.40 \\
\hline 4 & Vinogradovsky & 11 & 30 & 0.37 \\
\hline 5 & Kargopolsky & 8 & 30 & 0.27 \\
\hline 6 & Konoshsky & 9 & 30 & 0.30 \\
\hline 7 & Kotlassky & 15 & 30 & 0.50 \\
\hline 8 & Krasnoborsky & 13 & 30 & 0.43 \\
\hline 9 & Lensky & 12 & 30 & 0.40 \\
\hline 10 & Leshukonsky & 4.5 & 30 & 0.15 \\
\hline 11 & Mezensky & 6 & 30 & 0.20 \\
\hline 12 & Nyandomsky & 10 & 30 & 0.33 \\
\hline 13 & Onezhsky & 12 & 30 & 0.40 \\
\hline 14 & Pinezhsky & 13 & 30 & 0.43 \\
\hline 15 & Plesetskiy & 10 & 30 & 0.33 \\
\hline 16 & Primorsky & 15 & 30 & 0.50 \\
\hline 17 & Ustyansky & 13 & 30 & 0.43 \\
\hline 18 & Kholmogorsky & 13 & 30 & 0.43 \\
\hline 19 & Shenkursky & 12 & 30 & 0.40 \\
\hline
\end{tabular}

The calculated value of the $K_{2}$ criterion is then taken into account to assess the overall level of industrialization in the districts. 


\subsubsection{Industrial construction of low-rise residential buildings}

The analysis of territories showed that construction and installation organizations in the region are located in the administrative centers of municipal districts and/or in the largest settlements. The number of organizations in districts that offer residential construction services and the calculation of the evaluation criteria determined by formula 6 are presented in table 6.

Table 6. $K_{3}$ criterion calculation.

\begin{tabular}{|c|c|c|c|c|c|c|c|c|c|}
\hline No & 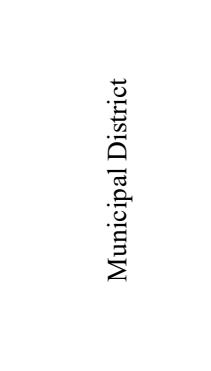 & 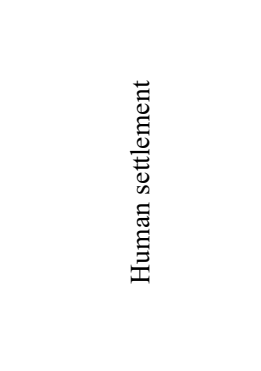 & 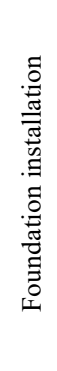 & 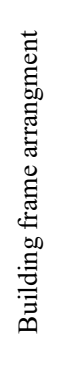 & $\begin{array}{l}\text { 告 } \\
\stackrel{0}{0} \\
\stackrel{0}{0}\end{array}$ & 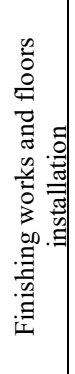 & 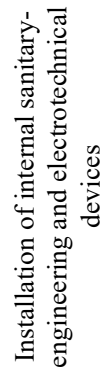 & 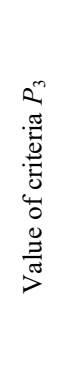 & 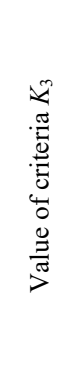 \\
\hline 1 & Velsky & Velsk & 2 & 2 & 2 & 2 & 2 & 10 & 1.0 \\
\hline 2 & Verkhnetoemsky & Verhnyaya Tojma & 1 & 1 & 1 & 1 & 0 & 4 & 0.4 \\
\hline 3 & Vilegodsky & Ilyinsko-Podomskoe & 0 & 0 & 0 & 0 & 0 & 0 & 0.0 \\
\hline 4 & Vinogradovsky & Bereznik & 0 & 0 & 0 & 0 & 0 & 0 & 0.0 \\
\hline 5 & Kargopolsky & Kargopol & 0 & 0 & 0 & 1 & 0 & 1 & 0.1 \\
\hline 6 & Konoshsky & Konosha & 0 & 0 & 0 & 1 & 0 & 1 & 0.1 \\
\hline 7 & Kotlassky & Kotlas & 2 & 2 & 2 & 2 & 1 & 9 & 0.9 \\
\hline 8 & Krasnoborsky & Krasnoborsk & 1 & 1 & 1 & 1 & 0 & 4 & 0.4 \\
\hline 9 & Lensky & Yarensk & 0 & 0 & 0 & 0 & 0 & 0 & 0.0 \\
\hline 10 & Leshukonsky & Leshukonskoe & 0 & 0 & 0 & 0 & 0 & 0 & 0.0 \\
\hline 11 & Mezensky & Mezen & 0 & 0 & 0 & 0 & 0 & 0 & 0.0 \\
\hline 12 & Nyandomsky & Nyandoma & 1 & 0 & 1 & 1 & 0 & 3 & 0.3 \\
\hline 13 & Onezhsky & Onega & 1 & 0 & 1 & 1 & 0 & 3 & 0.3 \\
\hline 14 & Pinezhsky & Karpogory & 0 & 0 & 0 & 0 & 0 & 0 & 0.0 \\
\hline 15 & Plesetskiy & Plesetsk & 0 & 0 & 0 & 1 & 0 & 1 & 0.1 \\
\hline 16 & Primorsky & Arkhangelsk & 2 & 2 & 2 & 2 & 2 & 10 & 1.0 \\
\hline 17 & Ustyansky & Oktyabrsky & 2 & 0 & 1 & 1 & 1 & 5 & 0.5 \\
\hline 18 & Kholmogorsky & Kholmogory & 0 & 0 & 0 & 0 & 0 & 0 & 0.0 \\
\hline 19 & Shenkursky & Shenkursk & 0 & 0 & 0 & 0 & 0 & 0 & 0.0 \\
\hline
\end{tabular}

The overall assessment of the level of industrialization in the districts of the Arkhangelsk region is made by summing up points for each of the criteria (Table 7). Depending on the range of the found value, the level of industrialization is determined.

Table 7. The overall assessment of the level of industrialization.

\begin{tabular}{|c|c|c|c|c|c|}
\hline No & Municipal District & criteria $K_{1}$ & criteria $K_{2}$ & criteria $K_{3}$ & Summ of criteria \\
\hline 1 & Velsky & 0 & 0.4 & 1 & 1.4 \\
\hline 2 & Verkhnetoemsky & 0 & 0.37 & 0.4 & 0.77 \\
\hline 3 & Vilegodsky & 0 & 0.4 & 0 & 0.4 \\
\hline 4 & Vinogradovsky & 0 & 0.37 & 0 & 0.37 \\
\hline 5 & Kargopolsky & 0 & 0.27 & 0.1 & 0.37 \\
\hline 6 & Konoshsky & 0 & 0.3 & 0.1 & 0.4 \\
\hline 7 & Kotlassky & 0 & 0.5 & 0.9 & 1.4 \\
\hline 8 & Krasnoborsky & 0 & 0.43 & 0.4 & 0.83 \\
\hline
\end{tabular}




\begin{tabular}{|c|c|c|c|c|c|}
\hline No & Municipal District & criteria $K_{1}$ & criteria $K_{2}$ & criteria $K_{3}$ & Summ of criteria \\
\hline 9 & Lensky & 0 & 0.4 & 0 & 0.4 \\
\hline 10 & Leshukonsky & 0 & 0.15 & 0 & 0.15 \\
\hline 11 & Mezensky & 0 & 0.2 & 0 & 0.2 \\
\hline 12 & Nyandomsky & 0 & 0.33 & 0.3 & 0.63 \\
\hline 13 & Onezhsky & 0 & 0.4 & 0.3 & 0.7 \\
\hline 14 & Pinezhsky & 0 & 0.43 & 0 & 0.43 \\
\hline 15 & Plesetskiy & 0 & 0.33 & 0.1 & 0.43 \\
\hline 16 & Primorsky & 0 & 0.5 & 1 & 1.5 \\
\hline 17 & Ustyansky & 0 & 0.43 & 0.5 & 0.93 \\
\hline 18 & Kholmogorsky & 0 & 0.43 & 0 & 0.43 \\
\hline 19 & Shenkursky & 0 & 0.4 & 0 & 0.4 \\
\hline
\end{tabular}

Thus, the districts of the Arkhangelsk region have medium and low levels of industrialization in terms of construction industrialization (figure 2).

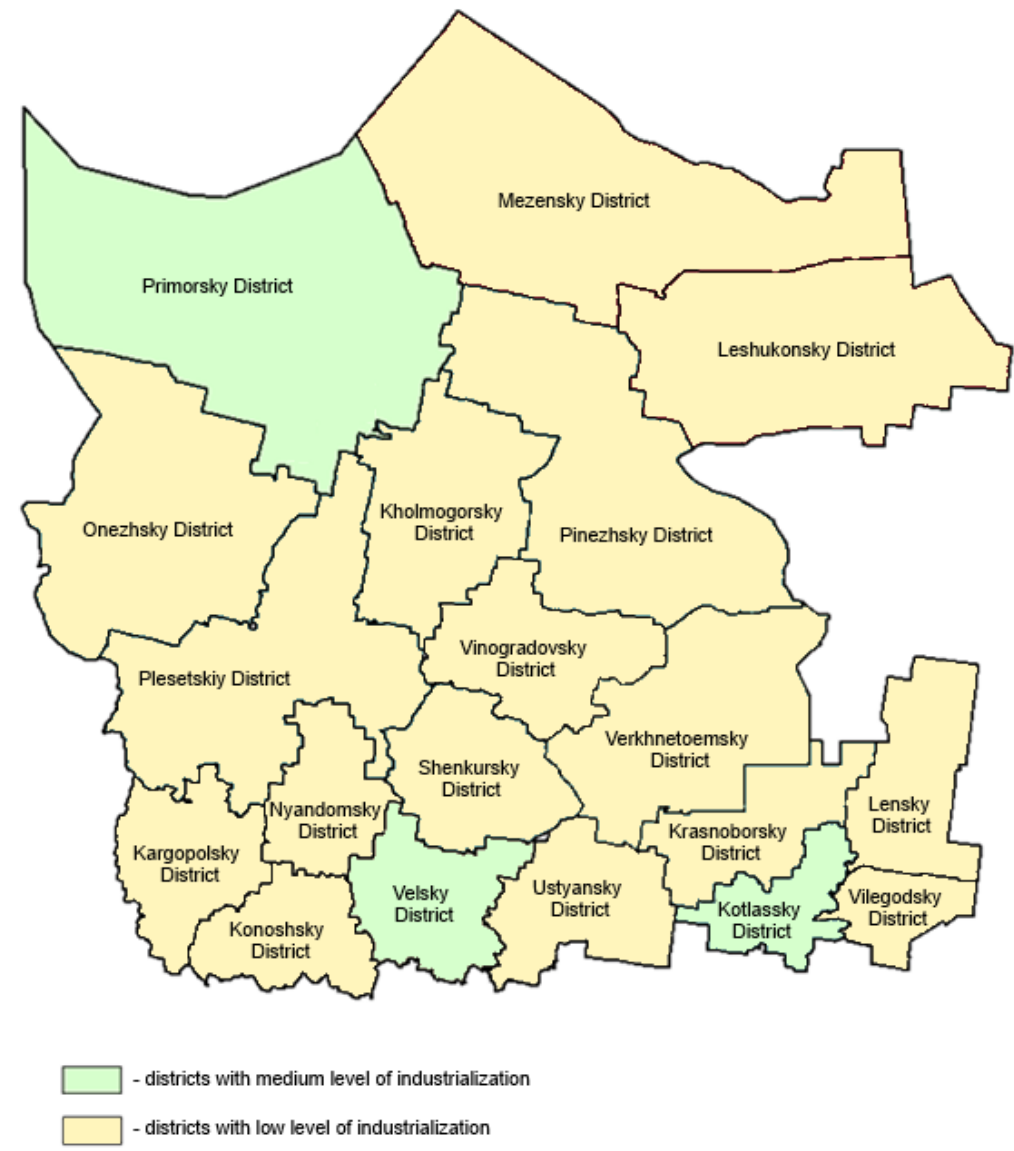

Fig. 3. Clustering of districts of the Arkhangelsk region by the level of industrialization.

Increasing the level of industrialization is possible due to: 
- development of projects that meet the requirements of efficiency, energy efficiency and environmental friendliness of construction for inclusion in the register of project documentation for reuse;

- development of existing production facilities and creation or restoration of liquidated enterprises on the basis of existing material and raw material bases in the region;

- increasing the production capacity of existing construction and installation organizations, including small and medium-sized businesses, and expanding the coverage of their service areas in the presence of public demand for housing.

Nowadays, the territory of the Arkhangelsk region has the following number of design companies engaged in design of residential houses:

- Primorsky district: Arkhangelsk-26, Severodvinsk-14, Novodvinsk-1;

village Shirshynskiy - 1;

- Plesetsky district: Mirny-1;

- Ustyansky district: Oktyabrsky - 1;

- Kotlas district: Kotlas - 1, Koryazhma - 1 .

These organizations develop project documentation for capital construction projects, including for low-rise residential buildings, which may increase the level of industrialization according to the criteria for the availability of projects for the territory in question that meet the requirements set by the Ministry of construction of the Russian Federation for inclusion in the register of project documentation for reuse.

In view of the absence and unprofitability of creating construction organizations in sparsely populated areas, it is possible to attract construction and installation organizations located in larger localities of the region to implement construction in rural areas of a particular district.

According to documents of territorial planning in the municipal districts of the Arkhangelsk region, it is planned to develop production of construction materials on the basis of the available raw material base that will enhance the level of industrialization of construction (table 8).

Table 8. Activities in the field of development of construction materials production planned for implementation in the Arkhangelsk region.

\begin{tabular}{|c|c|c|}
\hline No & $\begin{array}{c}\text { Municipal } \\
\text { District }\end{array}$ & Activities \\
\hline 1 & Velsky & $\begin{array}{l}\text { Organization of production of wooden building structures; construction } \\
\text { of enterprises for the production of frame and wooden houses }\end{array}$ \\
\hline 2 & Verkhnetoemsky & $\begin{array}{l}\text { Construction of enterprises for the manufacture of frame wooden } \\
\text { houses }\end{array}$ \\
\hline 3 & Vilegodsky & $\begin{array}{c}\text { Organization of a brick factory and production of wooden building } \\
\text { structures }\end{array}$ \\
\hline 4 & Vinogradovsky & $\begin{array}{l}\text { Organization of a brick factory and production of wooden building } \\
\text { structures }\end{array}$ \\
\hline 5 & Kargopolsky & $\begin{array}{c}\text { Construction of enterprises for the manufacture of frame wooden } \\
\text { houses }\end{array}$ \\
\hline 6 & Konoshsky & $\begin{array}{l}\text { Production of wooden building structures, construction of a mini- } \\
\text { factory for the production of bricks, construction of enterprises for the } \\
\text { production of frame wooden houses }\end{array}$ \\
\hline 7 & Kotlassky & $\begin{array}{l}\text { Placement of enterprises for the production of ceramic bricks, } \\
\text { construction of enterprises for the production of frame wooden houses }\end{array}$ \\
\hline 8 & Krasnoborsky & $\begin{array}{l}\text { Construction of a company for the manufacture of frame wooden } \\
\text { houses }\end{array}$ \\
\hline 9 & Lensky & $\begin{array}{c}\text { Organization of small-scale brick production, production of wooden } \\
\text { building structures }\end{array}$ \\
\hline 10 & Leshukonsky & Organization of production of wooden building structures \\
\hline
\end{tabular}




\begin{tabular}{|c|c|c|}
\hline No & $\begin{array}{c}\text { Municipal } \\
\text { District }\end{array}$ & Activities \\
\hline 11 & Mezensky & $\begin{array}{l}\text { Construction of an enterprise for the manufacture of frame wooden } \\
\text { houses; construction of small brick factories based on the deposit of } \\
\text { brick clays }\end{array}$ \\
\hline 12 & Nyandomsky & Construction of a brick factory \\
\hline 13 & Onezhsky & $\begin{array}{c}\text { Organization of production of wooden building structures, organization } \\
\text { of brick production }\end{array}$ \\
\hline 14 & Pinezhsky & $\begin{array}{c}\text { Organization of brick production, construction of enterprises for the } \\
\text { production of frame wooden houses }\end{array}$ \\
\hline 15 & Plesetskiy & $\begin{array}{c}\text { Organization of production of wooden building structures, organization } \\
\text { of production of reinforced concrete products }\end{array}$ \\
\hline 16 & Primorsky & $\begin{array}{l}\text { Organization of brick production, development of wooden house } \\
\text { construction, construction of enterprises for the production of frame } \\
\text { wooden houses }\end{array}$ \\
\hline 17 & Ustyansky & $\begin{array}{l}\text { Organization of production of wooden building structures, organization } \\
\text { of a brick factory }\end{array}$ \\
\hline 18 & Kholmogorsky & - \\
\hline 19 & Shenkursky & Production of wooden structures; panel-frame wooden houses \\
\hline
\end{tabular}

Implementation of activities to increase the level of industrialization in a particular territory is required in areas where there is a need to increase the volume of housing construction.

The indicator of housing provision in Leshukonsky, Mezenky, Kholmogorsky, Pinezhsky and Shenkursky districts is at a high level in comparison with other districts of the region. The analysis showed that high housing provision in these territories is achieved due to high rates of population decline. At the same time, the level of industrialization of construction in these areas is one of the lowest in the region. In this regard, the implementation of activities to increase the level of industrialization of these territories is not required.

Plesetsky, Onegsky, Konoshsky, Nyandomsky, Ustyansky and Lensky districts are the most in need of measures to increase the level of industrialization for all the considered criteria. The indicator of availability of housing suitable for living in these territories is lower than the average national value-25.0 sq. m. Slightly less need for measures to increase the level of industrialization is available in Krasnoborsky, Vilegodsky, Vinogradovsky, Kargopolsky and Verkhnetoyemsky districts, the value of housing provision of which varies from 25.3 to 28.6 sq. $\mathrm{m} /$ person.

In Velsky and Kotlassky districts, the housing supply index is lower than the national average and is 23.1 and 24.2 square meters / person, respectively, but the level of industrialization in these areas is one of the highest in the region. It is sufficient to increase the level of industrialization only by developing standard design documentation for lowrise buildings.

In the Primorsky region, the level of industrialization reaches the highest value in comparison with other districts of the Arkhangelsk region. Housing provision of the population of this territory is at a relatively high level -31 square meters/person. In this regard, the growth factor of industry in this territory is considered as measures to increase the level of industrialization of construction in the Primorsky region.

\section{Conclusion}

Industrialization of housing construction and conducting construction on standard projects will allow achieving significant progress in solving the housing problem, forming a new housing stock. The development of the construction industry, the transformation of the 
construction materials industry in remote and sparsely populated areas is a factor in the strong growth of the region's economy and the quality of life of citizens.

The proposed method allows identifying areas that are most in need of growth in the rate of housing construction, determining the level and potential of development of their construction industry. The presented methods and results are a tool for strategic planning of the region's development and allow determining the direction of development of investment and housing policy.

\section{References}

1. A. Dinçer, G. Çağdaş, H. Tong, Environmental Sciences, 22, 270-279 (2014) doi: 10.1016/j.proenv.2014.11.026

2. A. Rahim, Z. Hamid, I. Zen, Z. Ismail, K. Kamar, Social and Behavioral Sciences, 50, 369-382 (2012) doi: 10.1016/j.sbspro.2012.08.042

3. R. Ghaleh, J. Sardroud, Engineering, 164, 534-541 (2016) doi: 10.1016/j.proeng.2016.11.655

4. S. Isaac, T. Bock, Y. Stoliar, Procedia Engineering, 85, 274 - 282 (2014) doi: 10.1016/j.proeng.2014.10.552

5. J. Zhang, Y. Long, S. Lv, Y. Xiang, Procedia Engineering, 145, 1456 - 1461 (2016) doi: 10.1016/j.proeng.2016.04.183

6. I. Osipenkova, T. Simankina, T. Syrygina, V. Lukinov, E3S Web of Conferences, 33, 03045 (2018) doi: 10.1051/e3sconf/20183303045

7. T. Simankina, O. Sergeenkova. Applied Mechanics and Materials, 725-726, $984-989$ (2015) doi: 10.4028/www.scientific.net/AMM.725-726.984

8. N. Bari, N. Abdullah, R. Yusuff, N. Ismail, A. Jaapar, Social and Behavioral Sciences, 50, 392 - 404 (2012) doi: 10.1016/j.sbspro.2012.08.044

9. M. Fadhil, Social and Behavioral Sciences, 85, 8-15 (2013) doi: 10.1016/j.sbspro.2013.08.332

10. M. Musa, M. Mohammad, R. Mahbub, M. Yusof, Social and Behavioral Sciences, 153, 79 - 89 (2014) doi: 10.1016/j.sbspro.2014.10.043

11. N. Nanyam, A.Sawhney, P. Gupta, Engineering, 196, 135-143 (2017) doi: 10.1016/j.proeng.2017.07.183

12. U. Kassim, L. Walid, Procedia Engineering, 53, 58 - 63 (2013) doi: 10.1016/j.proeng.2013.02.010

13. R. Milwicz, P. Nowotarski, Procedia Engineering, 122, 158 - 165 (2015) doi: 10.1016/j.proeng.2015.10.020

14. J. Molavi, D. L Barral, Procedia Engineering, 145, 1362 - 1369 (2016) doi: 10.1016/j.proeng.2016.04.201

15. E. Generalova, V. Generalov, A. Kuznetsova, Procedia Engineering, 153, $167-172$ (2016) doi: 10.1016/j.proeng.2016.08.098

16. D. Lopez, T. M Froese, Procedia Engineering, 145, 1291 - 1297 (2016) doi: 10.1016/j.proeng.2016.04.166

17. J. Woo, Procedia Engineering, 180, $365-372$ (2017) doi: 10.1016/j.proeng.2017.04.195

18. M. Dave, B. Watson, D. Prasad, Procedia Engineering, 180, 676 - 686 (2017) doi: 10.1016/j.proeng.2017.04.227 